\title{
EPTS Curriculum Model in the Education of Gifted Students
}

\author{
Ugur Sak* \\ Anadolu University (Turkey).
}

\begin{abstract}
Título: El Modelo de curriculum EPTS para la Educación de los Alumnos Superdotados.

Resumen: En este artículo el autor revisa el modelo de los Programas para alumnos Superdotados y Talentos (EPTS, por sus siglas en inglés) desarrollados en la Anadolu University. Se discute como dichos programas se han desarrollado a través de múltiples fases, la forma en que estos se usan para desarrollar programas educativos para alumnos superdotados y la investigación llevada a cabo sobre la efectividad de este modelo educativo. El modelo EPTS tiene dos dimensiones: habilidad y contenido. La dimensión de habilidad tiene una estructura jerárquica compuesta por tres niveles de destrezas cognitivas. La dimensión de contenido es la extensión del currículo ordinario pero organizado en cuatro niveles: datos, conceptos, generalización y teoría. En el artículo también se incluye una breve crítica sobre el estado actual de los programas curriculares en la educación de alumnos superdotados.

Palabras clave: Educación de alumnos superdotados, EPTS, Curriculum para superdotados.
\end{abstract}

\section{Introduction}

A good curriculum for gifted students should include certain design parameters (Borland, 1989; Maker \& Schiever, 2010; Tomlinson, 2008; Van Tassel-Baska, 1998). This is not the case for most programs in gifted education. Tomlinson (2009) used the "patchwork" metaphor to describe current programs in gifted education that lack essential parameters. According to this metaphor, curriculum for gifted students has represented a patch-on approach by default over the years. A patchy program is detached from the general curriculum, and it is an extra rather than an extension of the regular classroom content, it does not have a coherent scope and sequence of content and skills across grades, and it lacks articulated elements such as a specified philosophy and welldefined goals and learning outcomes.

Even though having such drawbacks, many programs in gifted education have sustained its existence for years. The survival of such programs in gifted education is no surprise as there is so much need and parental support for special education for gifted students. Indeed, Van Tassel-Baska and Brown (2007) asserted that gifted education as a field around the world relies on faithful application of curriculum and program models. If true, this claim invalidates the necessity, not the scientific rationale, of many gifted education programs currently under administration. This claim also uncovers the fact that the influence of many of the models on the growth of gifted students is unknown or unproven. For example, Van Tassel-Baska and Brown (2007) reviewed existing program and curriculum models frequently used in

* Dirección para correspondencia [Correspondence address]:

Ugur Sak. Prof., Director, Center for Practice and Research on Gifted Education, Anadolu University. Department of Special Education. 26470 Eskisehir (Turkey). E-mail: usak@,anadolu.edu.tr

\begin{abstract}
In this article, the author reviews the EPTS Model (Education Programs for Talented Students) and discuss how it was developed through multiple stages, the ways it is used to develop programs for gifted students, and then presents research carried out on the effectiveness of this model in the education of gifted students. The EPTS Model has two dimensions: ability and content. The ability dimension has a hierarchical structure composed of three levels of cognitive skills. The content dimension is the extension of the regular curriculum but organized at four levels: data, concept, generalization and theory. Included in the article also is a brief critics of the current state of curricular programs in gifted education. Key words: Gifted Education, acceleration, EPTS, Gifted curriculum.
\end{abstract}

gifted education and determined any evidence of effectiveness for their use with gifted populations. They identified 20 models frequently used with gifted students; but, only 11 of them met the criteria for a curriculum model. Of these models, unfortunately only five were found to have some evidence of effectiveness with gifted students.

The EPTS (Education Programs for Talented Students) Curriculum is a universal model, and therefore can be used to develop both enriched and accelerated-enriched curricular programs for gifted students for most subject areas in most program options at all grade levels. The EPTS Curriculum model includes the four principles that are important parameters in the curriculum design for gifted students. These are universality, specificity, utility, and flexibility. These principles also are supported by leading experts in curriculum models for the gifted (e.g., Tomlinson 2009; Van TasselBaska \& Brown; 2007). According to the universality principle, curriculum for the gifted should be applicable across a variety of grouping settings, such as special schools, selfcontained classrooms and pull-out programs. Specificity principle suggests that the curriculum should have welldefined specific learning outcomes identified based on specific learning needs of gifted students. Utility principle allows the curriculum to be applied to most subject areas, such as science and mathematics. Lastly, according to the flexibility principle, the curriculum model should be applicable across all grade levels. In short, a curriculum model for gifted education is not sufficient and comprehensive enough if it is only for a particular grade level or a specific subject area or if it does not have systematic elements for designing curricular programs. 


\section{EPTS Curriculum Model}

The EPTS Curriculum Model is a comprehensive skill and content-based model for developing programs in the education for gifted students (Sak, 2009b, 2011a, 2011b, 2013). It was developed based on an integration of the theory of successful intelligence (Sternberg, 1997) and its teaching principles (Sternberg \& Grigorenko, 2000, 2007), and research on creativity and problem solving. Sternberg (1997) identified analytical, creative and practical abilities as components of intelligence and suggested that successful people use all three abilities to achieve success.

The theory of successful intelligence explains intellectual bases of success. However, what is missing in a curriculum based on this theory to foster excellence is the content or knowledge component. Knowledge is a requisite component for excellence since excellence is built on experience and knowledge (Ackerman \& Beier, 2003; Ericsson, 2006; Ericsson, Nandagopal \& Roring, 2005). For example, based on the theory of successful intelligence, Sak (2009a) proposed a model of mathematical ability that included knowledge as well as the abilities of the successful intelligence as essential components of excellence. The analytical, creative and practical components are necessary but insufficient for excellent performance in any fields. Likewise, knowledge component also is a necessary but insufficient component for excellence. That is, these components are jointly sufficient for excellence.

The EPTS Curriculum has two dimensions (Sak, 2011a, 2011b). The first of the dimensions includes three components of ability (figure 1). The second dimension is com- posed of content component. The ability component was developed through four stages. First, the analytical, practical and creative components of successful intelligence were used as the first-order ability to construct a general framework for the new model. Then, all of the original skills of these components defined in the theory were evaluated for their importance, and thirty-five of them were selected to be appropriate for the model. After some of these skills were revised, they were integrated in the model as the secondorder broad skills. Second, new second-order broad skills were identified through the review of literature on creativity and problem solving and included in the model. Third, the second-order skills were further analyzed through the review of related literature to identify their subskills that could be used as specific learning and development outcomes. The analysis yielded a substantial number of subskills. Then, they were defined and labeled as the third-order subskills. Fourth, the sub-skills were evaluated for their importance and appropriateness before they were added to the model as the third-order subskills. The final EPTS curriculum included three first-order abilities, 43 second-order skills and 152 third-order sub-skills (see Appendix A, B and C). These subskills were labeled as the EPTS skills. The analytical component includes eight broad skills, such as problem defining and forecasting, and twenty-eight sub-skills. The creativity component has seventeen broad skills, such as idea generation and creative imagination, and fifty-eight sub-skills. The practical component consists of eighteen broad skills, such as setting priorities and completing tasks, and sixty-six subskills.

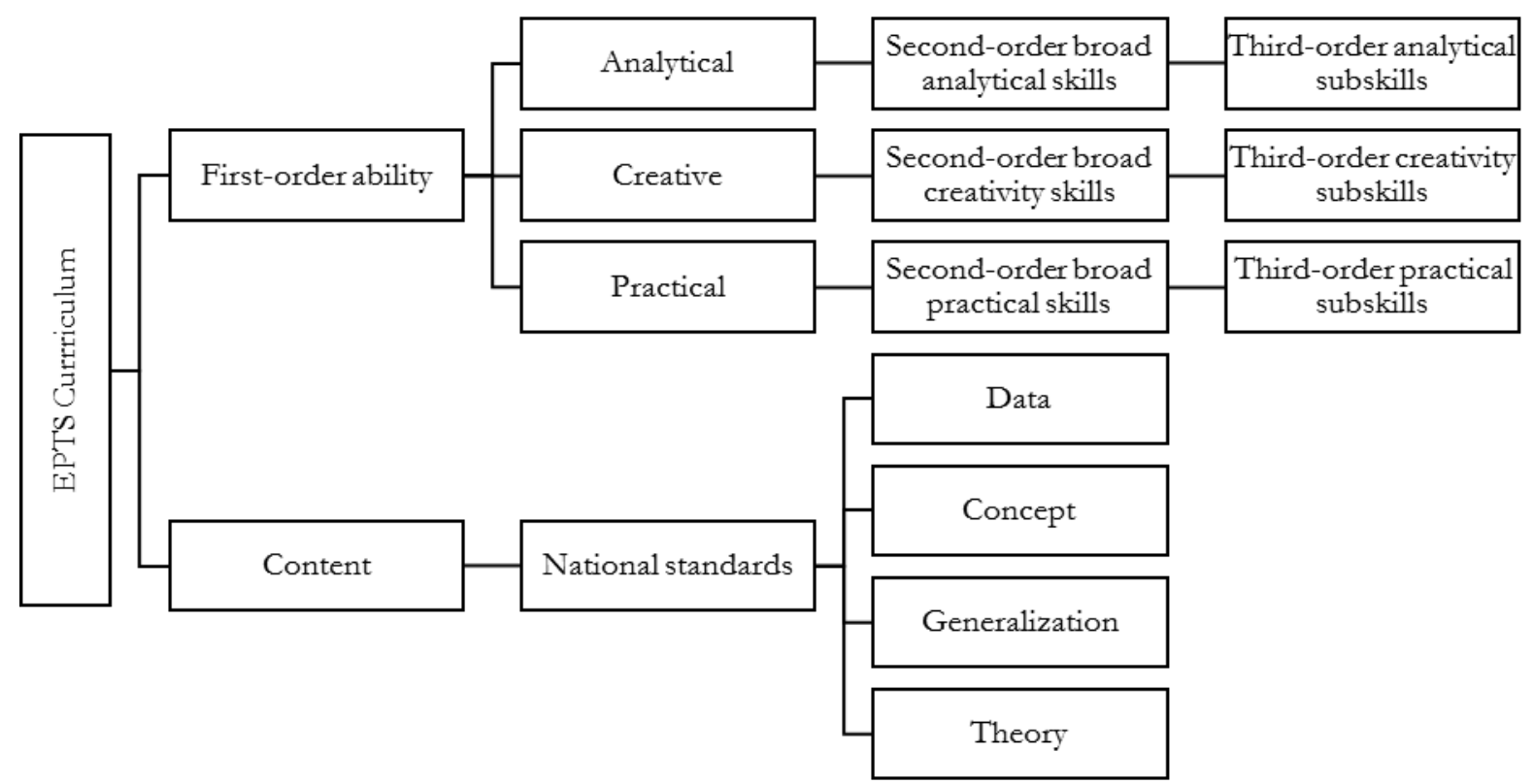

Figure 1. EPTS Curriculum Model. 
The content component of the EPTS is composed of national standards at each grade level and used with the EPTS skills for developing accelerated and enriched theme, unit or lesson plans. Contrary to the ability component, this component of the EPTS curriculum does not have specific learning outcomes; instead national standards both at the regular level and accelerated level at each grade are suggested to be used because national standards vary both from country to country and from grade to grade. However, in developing curricular themes, units and lessons using the EPTS Model, content standards are revised according to Banks and Clegg's classification of knowledge (Banks \& Clegg, 1990). The classification includes four levels of knowledge: data, concept, generalization and theory. Data refers to factual knowledge. For example, the number of languages spoken in the world is a factual knowledge. Conceptual knowledge is an abstract idea drawn from particular instances. World language, for example, is a concept referring to a language spoken internationally. Generalization refers to general statements, laws, principles or propositions about the whole drawn from the parts of the whole. For instance, the proposition that languages that do not have written language disappear over time is a generalization based on particular cases. Theories are the highest level of knowledge. A theory is an idea or a set of ideas, generalizations or propositions offered to explain some phenomenon. For example, the gestural theory about the origin of languages are based on several hypotheses, generalizations and evidence (Lefebvre, Comrie \& Cohen, 2013). National standards often include data and concept levels only but excludes generalization and theory levels. The inclusion of four levels of content in the EPTS programs better promotes conceptual learning.

\section{Development of Enriched and Accelerated Programs Using the EPTS Curriculum}

Acceleration and enrichment have been the dominant approaches for differentiating the education for gifted students. According to some researchers, acceleration is viewed to be one of the most ideal models in educating gifted students (Colangelo, Assouline \& Gross, 2004; Stanley, 1977; Van'Tassel-Baska, 2005) whereas enrichment is so deemed by others (Renzulli \& Reis, 2000). For example, Steenbergen-Hu and Moon (2011) did a meta-analysis on the effects of acceleration on gifted students' academic achievement. They reviewed 38 studies published from 1984 to 2008. The results of the study showed that acceleration had positive impact on students' academic achievement. Nevertheless, meta-analytic studies have shown both approaches to have positive learning effects when they are well-designed and used together (Kulik \& Kulik, 1992). Indeed, one of the key beliefs guiding the most curriculum models in gifted education is that confluent approaches that allow for both advanced content learning and enriched experiences should be used for serving gifted students (Triffinger, Nassab \& Selby, 2009; Van'Tassel-Baska, 2000).

Aligned with research findings, the EPTS Curriculum is used together with both enrichment and acceleration approaches to develop curricular programs for gifted students (Sak, 2011a). The EPTS skills are integrated with standards of the regular curriculum or advanced contents using the EPTS Lesson Plan Form (Appendix D) to develop enriched and accelerated-enriched EPTS programs that include both ability outcomes and knowledge outcomes (see figure 2). As shown in figure 2, the combination of the 152 EPTS skills together with regular content standards and accelerated content standards produces a possibility for the development of numerous different lesson plans at each grade level. Acceleration is carried out by transferring higher-grade level contents. Any content acceleration also contains enrichment activities designed by integrating the EPTS skills into the accelerated content. This way of acceleration and enrichment promotes the development of advanced content knowledge, conceptual learning and enhancement of higher-order thinking skills.

The purpose of the enrichment of the EPTS is to develop process skills in students and to make their knowledge applicable outside the learning situation. Acquisition of knowledge that is transferable in different situations is a complex learning leading to cognitive flexibility (Gruber \& Mandl, 2000). EPTS units are designed so that the same concepts are treated in different units as transversal contents, facilitating their transferability. Transferability of knowledge also is the basis of interdisciplinary learning, a principle recommended for the education of gifted students (Maker, 1982; Maker \& Schiever, 2010; VanTassel-Baska, 1992). Transferability of knowledge increases by the use of multiple perspectives on problem solving rather than through abstract context-free learning (Gruber \& Mandl, 2000). Applied in gifted education, the single use of acceleration with an emphasis primarily on learning advanced content helps students learn those contents, but could lead to decontextualized learning, and therefore may not result in the acquisition of transferable knowledge. This idea is one of the rationales for combining enrichment and acceleration in the EPTS. 


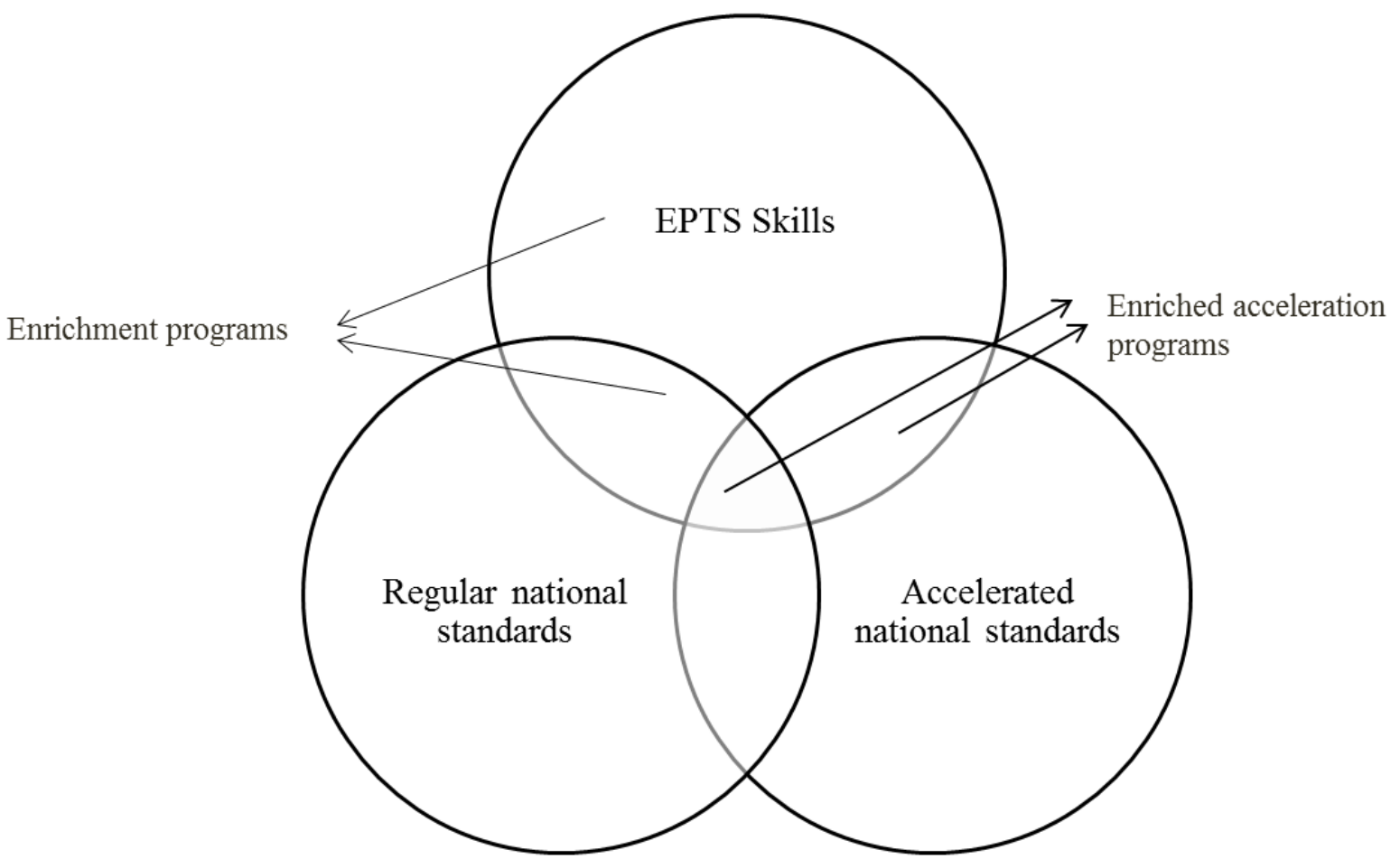

Figure 2. Combination of the EPTS Skills and Content Standards in the Development of Lesson Plans.

\section{Research on the EPTS Curriculum}

Research has been conducted to support the effectiveness of the EPTS Curriculum with gifted students within a variety of educational settings during the last six years. Specifically, significant growth gains in mathematical creativity and competency, scientific creativity and creative writing and linguistic competency have been demonstrated for gifted classes using the developed curriculum units in language arts, science and mathematics.

In some studies, the EPTS Curriculum was used to teach sixth, seventh and eighth grade gifted students in an after school program for gifted students at Anadolu University. During the implementation of these programs, growth in gifted students' mathematical creativity and scientific creativity regularly were measured using the Creative Mathematical Ability Test and the Creative Scientific Ability Test in pretest and posttest settings (Ayas, 2012; Sak, 2013, 2014; Sak, Demirel-Gürbüz, Bal-Sezerel, Ayas \& Özdemir, 2013; Sak \& Karabacak, 2010; Sak, Karabacak \& Kilıç, 2009). In these studies, gifted students' creativity both in mathematical domain and in scientific domain was found to increase significantly from pretest measurements to posttest measurements. Specifically, after students attended the EPTS, they produced more creative hypotheses about scientific facts, designed more effective experiments to test hypotheses, and evaluated scientific evidences more effectively. In the mathematical domain, they posed more original problems and developed more original strategies and methods to solve mathematical problems.
In another study, the social validity of the EPTS was investigated. This study included an examination of middleschool gifted students' perceptions about the EPTS programs offered as after-school programs at Anadolu University and their satisfaction with the quality of the programs. Findings showed that students had high satisfaction with the EPTS programs, an evidence for the social validity of the EPTS (Sak, 2011a; Sak, et. al., 2013). Social validity studies are important for education programs for gifted students; because they show students' perceptions and satisfactions about these programs and the sustainability of these programs are mainly dependent upon students' satisfactions and positive perceptions. Indeed, most withdrawals of gifted students from special education programs presumably result from their dissatisfaction with these programs.

The EPTS Curriculum also has been used in developing programs for gifted students in full-time self-contained classes in Anabilim Schools in Istanbul, the first project school where the EPTS model was applied. In this project, special programs for mathematics, language arts, social studies and science courses were developed at the first, second, third and fourth grades using the EPTS Curriculum Model and national standards. The program of each course included five to seven themes and each theme was composed of four to five lesson plans. All of the themes in mathematics were extensions of the regular curriculum whereas the themes in the other courses were either extensions of the regular curriculum or completely unique, such as electricity as an extension and extraordinary habitats as a unique theme in science. At least $25 \%$ of the content of all the courses included upper 
grade standards. The programs for these courses incorporated both enrichment in content and process and acceleration in content. A program book for teachers and a workbook for students were developed for each course. In order to teach these courses, the regular courses of students were compacted and accelerated $40 \%$. In the remaining time, the EPTS programs were used as parallel programs to the regular courses throughout the school years. During the project, students' creative thinking and problem solving skills in reading, writing, mathematics, and science were measured in pretest and posttest settings at each grade level. In all the comparisons, students were found to have significant gain scores (Sağlam-Demir \& Aksoy-Pehlivan, 2013; Sak, Akyol, Sağlam-Demir, Aksoy-Pehlivan, Dora, Özdek \& Karakan, 2014). Particularly important finding in these studies was students' progress in analytical and creative thinking. Stu-

\section{References}

Ayas, M. B. (2012). ÜYEP fen bilimleri müfredatının değerlendirilmesi [An evaluation of the UYEP Science programs]. 3. Türkiye Üstün Yetenekli Cocuklar Kongresi, Ankara, Turkey.

Ackerman, P., \& Beier, M. E. (2003). Trait complexities, cognitive investment, and domain knowledge. In R.J. Sternberg \& E. L. Grigorenko (Eds.), The psychology of abilities, competencies, and expertise (1-30). New York: Cambridge University Press.

Banks, J. A., Clegg, A. A. (1990). Teaching strategies for the social studies: Inquiry, valuing, and decision-making (4th $\mathrm{ed}$.). New York: Longman.

Borland, J. H. (1989). Planning and implementing programs for the gifted and talented. New York: Teachers College Press.

Colangelo, N., Assouline, S., \& Gross, M. U. M. (2004). A nation deceived: How schools bold back America's brightest students (Vol.I). Iowa City: The Connie Belin \& Jacqueline N. Blank International Center for Gifted Education and Talent Development, The University of Iowa.

Ericsson, K. A. (2006). The influence of experience and deliberate practice on the development of expert performance. In K. A. Ericsson, N. Charness, P. J. Feltovich \& R. R. Hoffman (Eds.), The Cambridge handbookof expertise and expert performance (683-704). New York: Cambridge University Press.

Ericsson, K. A., Nandagopal, K., \& Roring, R. W. (2005). Giftedness viewed from the expert-performance perspective. Journal for the Education of the Gifted, 28, 3/4, 287-311.

Lefebvre, C., Comrie, B., \& Cohen, H. (Eds.). (2013). New perspectives on the origin of language. Studies in Language Companion Series, Book 144. Amsterdam: John Benjamins Publishing Company.

Gruber, H., \& Mandl, H. (2000). Instructional psychology and the gifted. In K. A. Heller, F. J. Mönks, R. J. Sternberg \& R. F. Subotnik (Eds.), International bandbook of giftedness and talent (2nd ed.), (pp. 383-396). Oxford, UK: Elsevier Science Ltd.

Kulik, J.A., \& Kulik, C.C. (1992). Meta analytic findings on grouping programs. Gifted Child Quarterly, 36, 73-77.

Maker, C. J. (1982). Curriculum development for the gifted. Rockville, Maryland: Aspen System Corporation.

Maker, C. J., \& Schiever, S. W. (2010). Curriculum development and teaching strategies for gifted learners. Austin, TX: pro-ed.

Renzulli, J. S., \& Reis, S. M. (2000). The Schoolwide Enrichment Model. In K. A. Heller, F. J. Mönks, R. J. Sternberg \& R. F. Subotnik (Eds), International handbook of giftedness and talent (2nd $\mathrm{ed}$. pp 367-382). Oxford, UK: Elsevier Science Ltd.

Sağlam-Demir, K., \& Aksoy-Pehlivan, T. (2013). Anabilim UYEP modelinin üstün yetenekli ögrencilerin akademik gelisimleri üzerindeki etkisi [The effects of the Anabilim UYEP model on gifted students' academic development]. Paper presented at the third International Conference on Talent Development and Excellence, Antalya, Turkey. dents were found to do much better in finding and redefining problems, producing ideas, constructing different types of analogies and associations and developing strategies for solving problems.

In conclusion, the EPTS Curriculum Model has been found effective in the education of gifted students in a variety of domains in both self-contained classrooms and afterschool programs at different grade levels. Our next research agenda is to extend our research on the effectiveness of the EPTS Model on gifted students' thinking and problem solving skills in other areas, such as social domains. Finally, the EPTS team keeps working on the EPTS Curriculum Model with an emphasis on analyses of intelligence, creativity, problem solving and learning theories to identify new thinking and problem solving skills that could be integrated in the EPTS Curriculum Model.

Sak, U. (2009a). Test of the three-mathematical minds (M3) for the identification of mathematically gifted students. Roeper Review, 31, 53-67.

Sak, U. (2009b). Üstün yetenekliler eğitim programlar [Education programs for talented students]. Ankara: Maya Akademi.

Sak, U. (2011a). An overview of the social validity of the Education Programs for Talented Students Model (EPTS). Education and Science, 36, 213-229.

Sak, U. (2011b). Üstün zekallar: Özellikeleri tamlanmalar eğitimleri. 2. bas. (The gifted: Characteristics, identification and education. 2nd ed.). Ankara: Vize yayıncilik.

Sak, U. (2013). Education Programs for Talented Students Model (EPTS) and its effectiveness on gifted students' mathematical creativity. Education and Science, 38, 169, 51-61.

Sak. U. (2014): ÜYEP Modeli: Üstün yeteneklilerin eğitimi akıl oyunları değildir [Model UYEP: Education for gifted students is not mind game]. Panel bildirisi. 4. Ulusal Üstün Zekah ve Yeteneklilerin Eğitimi Kongresi. İstanbul, Turkey.

Sak, U., Demirel-Gürbüz, S., Bal-Sezerel, B., Ayas, M. B., \& Özdemir, N. N. (2013). Dünden bugüne ÜYEP: Bilimsel araștırmalar ve uygulamalar. [UYEO from yesterday to today: research and practices on UYEP]. Paper presented at the Third International Conference on Talent Development \& Excellence, 25-28 September, Antalya, Turkey.

Sak, U., \& Karabacak, F. (2010). What research says about the Education Programs for Talented Students (EPTS). 12th ECHA Conference, Paris, France.

Sak, U., Karabacak, F., \& Kılıç, A. (2009). Üstün Yetenekliler Eğitim Programları (ÜYEP): Tanılama, Öğretim ve Değerlendirme Biçimleri ve Programın Öğrenciler Üzerindeki Etkileri [Education Programs for Talented Students (UYEP):identification, teaching and assessment]. Üstün Yetenekli Cocuklar II. Ulusal Kongresi, Eskişehir, Turkey.

Sak, U., Akyol, G., Sağlam-Demir, K., Aksoy-Pehlivan, T., Dora, S., Özdek, S., \& Karakan, Y. (2014). Anabilim UYEP Model: A special program model for self-contained classrooms for the gifted in Turkey. Paper presented at 14th International ECHA Conference, Ljubljana, Slovenia.

Stanley, J. S. (1977). Rationale of the Study of Mathematically Precocous Youth (SMPY) during its first five years of promoting educational acceleration. In J. C. Stanley, W. C. George \& C. H. Solano (Eds.), the gifted and the creative: A fifty-year perspective (pp. 75-112). Baltimore: The Johns Hopkins University Press.

Steenbergen-Hu, S., \& Moon, S. M. (2011). The effects of acceleration on high-ability learners: A meta-analysis. Gifted Child Quarterly, 55(1), 39-53. Sternberg, R. J. (1997). Successful intelligence. New York: Plume.

Sternberg, R. J., \& Grigorenko, E. L. (2000). Teaching for successful intelligence. Thousand Oaks, CA: Corwin Press. 
Sternberg, R. J., \& Grigorenko, E. L. (2007). Teaching for successful intelligence. (2nd ed.). Arlington Heights, IL: SkyLight.

Tomlinson, C. A. (2008). Differentiated instruction. In J. A. Plucker \& C. M. Callahan (Eds.), Critical issues and practices in gifted education (pp. 167-177). Waco, TX: Pruffrock Press.

Tomlinson, C. A. (2009). Myth 8: The "patch-on" approach to programming is effective. Gifted Child Quarterly, 53, 254-256.

Triffinger, D., Nassab, C. A., Selby, E. C., (2009). Programming for talent development: expanding horizons for gifted education. In T. Bolchin, B. Hymer \& D. J. Matthews (Eds.), The Routledge international companion to gifted education (pp. 2010-2017). New York: Routledge.

VanTassel-Baska, J. (1998). A comprehensive model of program development. In J. VanTassel-Baska (Ed.), Excellence in educating gifted and talented learners. (pp. 309-334). Denver: Love.
VanTassel-Baska, J. (2000). Theory and research on curriculum development for the gifted. In K. A. Heller, F. J. Mönks, R. J. Sternberg \& R. F. Subotnik (Eds.), International handbook of giftedness and talent (2nd ed. pp 345365). Oxford, UK: Elsevier Science Ltd.

VanTassel-Baska, J. (2005). Acceleration: Strategies for teacbing gifted learners. Waco, TX: Prufrock Press, Inc.

Van Tassel-Baska, J., \& Brown, E. F. (2007). Toward best practice: An analysis of the efficacy of curriculum models in gifted education, Gifted Child Quarterly, 51, 342-358.

(Article received: 01-11-2015; revised: 16-12-2015; accepted: 31-12-2015) 
Appendix A. EPTS Analytical Ability Skills

\begin{tabular}{|c|c|c|}
\hline $\begin{array}{l}\text { Broad Skills } \\
\text { (2nd Order) }\end{array}$ & $\begin{array}{l}\text { Subskills } \\
\text { (3rd Order) }\end{array}$ & Definition \\
\hline \multirow[t]{4}{*}{ 1. Identify problems } & 1. Recognize problems & Recognize the existence of a problem \\
\hline & 2. Differentiate problems & Discriminate among problems and distinguish the real problem causing the result \\
\hline & 3. Understand problems & $\begin{array}{l}\text { Describe the nature and causes of problems in detail and relationships between causes } \\
\text { and problems }\end{array}$ \\
\hline & 4. Define problems & Define or explain problems concisely \\
\hline \multirow[t]{3}{*}{ 2. Plan resources } & 5. Partition time & Partition time according to work and work according to time \\
\hline & 6. Partition work & Partition work according to individual characteristics \\
\hline & 7. Balance & Make a balance between production and consumption \\
\hline \multirow[t]{4}{*}{$\begin{array}{l}\text { 3. Organize } \\
\text { information }\end{array}$} & 8. Classify information & $\begin{array}{l}\text { Categorize, organize, order or rank information or data according to similarities or } \\
\text { commonalities }\end{array}$ \\
\hline & 9. Construct relations & Make relations among data or information \\
\hline & 10. Describe information & Explain information from many perspectives \\
\hline & 11. Communicate & Orally or symbolically present information \\
\hline \multirow{4}{*}{$\begin{array}{ll}\text { 4. } & \text { Develop } \\
& \text { strategies }\end{array}$} & 12. Develop outlines & Develop a general outline for problem solving process \\
\hline & 13. Formulate solution plans & Develop successive stages for problem solving \\
\hline & 14. Develop alternatives & Produce alternative solutions for possibilities \\
\hline & 15. Evaluate strategies & Evaluate and assess solution plans \\
\hline \multirow{2}{*}{$\begin{array}{l}\text { Monitor problem } \\
\text { solving }\end{array}$} & 16. Observe strategies & Examine problem solving steps \\
\hline & 17. Verify solutions & Verify quality of solutions \\
\hline \multirow[t]{3}{*}{ 6. Evaluate results } & 18. Compare results & Compare results with certain criteria \\
\hline & 19. Subjective evaluation & Determine the value of results using different perspectives \\
\hline & 20. Objective evaluation & Determine the value of results using objective criteria \\
\hline \multirow[t]{5}{*}{ 7. Make decisions } & 21. Analyze data & Analyze data related to decisions \\
\hline & 22. Produce decisions & Produce logical decisions based on data \\
\hline & 23. Generate criteria & Generate criteria to choose among decisions \\
\hline & 24. Compare decisions & Compare and contrast decisions using criteria \\
\hline & 25. Choose decisions & Choose most appropriate decisions \\
\hline \multirow[t]{3}{*}{ 8. Forecasting } & 26. Construct relations & Construct cause-effect relations \\
\hline & 27. Predict & Predict consequences or effects \\
\hline & 28. Postdict & Postdict causes of results \\
\hline
\end{tabular}


Appendix B. EPTS Creativity Skills

\begin{tabular}{|c|c|c|}
\hline $\begin{array}{l}\text { Broad Skills } \\
\text { (2nd Order) }\end{array}$ & $\begin{array}{l}\text { Subskills } \\
\text { (3rd Order) }\end{array}$ & Definition \\
\hline \multirow[t]{2}{*}{ 1. Redefine problems } & 1. Restate problems & $\begin{array}{l}\text { Represent problems, ideas or products in different verbal, visual or symbolic } \\
\text { ways }\end{array}$ \\
\hline & 2. Reconstruct problems & Change the structure of problems, ideas or products \\
\hline \multirow[t]{2}{*}{ 2. Question assumptions } & 3. Critique assumptions & Critique prevalent beliefs, rules, dogmas and scientific knowledge \\
\hline & 4. Develop alternatives & Develop alternative arguments against prevalent assumptions \\
\hline \multirow[t]{4}{*}{ 3. Generate ideas } & 5. Fluent idea generation & Generate many ideas for a problem \\
\hline & 6. Flexible idea generation & Generate varied ideas for a problem \\
\hline & 7. Original idea generation & Generate unusual ideas for a problem \\
\hline & 8. Detailed idea generation & Add details to ideas \\
\hline \multirow[t]{4}{*}{ 4. Market creative ideas } & 9. Emphasize on strengths & $\begin{array}{l}\text { Convince others by emphasizing strengths and future benefits of ideas or } \\
\text { products }\end{array}$ \\
\hline & 10. Emphasize on weaknesses & Convince others by emphasizing weaknesses of other ideas or products \\
\hline & 11. Prove differences & Demonstrate differences of ideas or products from other ideas or products \\
\hline & 12. Select the true target & Select the most appropriate audience for marketing ideas and products \\
\hline \multirow[t]{3}{*}{ 5. Creative imagination } & 13. Descriptive imagination & Visualize details or development of events, ideas or products \\
\hline & 14. Sequential imagination & Envision sequential consequences of behaviors, events or inventions \\
\hline & 15. Mental rotation & Rotate and transform objects in mind \\
\hline \multirow{4}{*}{$\begin{array}{l}\text { 6. Perceive multiple } \\
\text { facets of knowledge }\end{array}$} & 16. Objective interpretation & Interpret an idea from all perspectives \\
\hline & 17. Subjective interpretation & Interpret one's ideas from your perspective \\
\hline & 18. Rationalize similarity & Explain an idea according to one's perspective \\
\hline & 19. Build empathy & Evaluate ideas by putting yourself into others' shoes \\
\hline \multirow[t]{4}{*}{ 7. Overcome obstacles } & 20. Identify real problems & Identify the real problem causing the challenge \\
\hline & 21. Persevere trying & Persist trying in spite of difficulties \\
\hline & 22. Determine optimal time & Find out the best time to solve problems \\
\hline & 23. Develop solution strategies & Develop strategies to overcome obstacles \\
\hline \multirow[t]{6}{*}{ 8. Take risks } & 24. Identify risks & Identify true risks \\
\hline & 25. Evaluate risks & Evaluate significance of risks \\
\hline & 26. Identify sensible risks & Identify and select risks that could be handled \\
\hline & 27. Take sensible risks & Take sensible risks by evaluating risks' qualities \\
\hline & 28. Control fear of failure & Start tasks with small and easy steps \\
\hline & 29. Try new ideas & Try unusual ideas or approaches that are different from the general \\
\hline \multirow[t]{2}{*}{ 9. Tolerate ambiguity } & 30. Persist on creativity & Persist working until achieving the creative result \\
\hline & 31. Incubation & Wait in a conscious period to achieve the best result \\
\hline \multirow[t]{4}{*}{ 10. Build self-efficacy } & 32. Develop goals & Develop goals for personal growth \\
\hline & 33. Explore personal capacity & Clarify real capacity by examining earlier achievements \\
\hline & 34. Initiate without hesitation & Put ideas into practice without hesitations \\
\hline & 35. Succeed based on goals & Complete goals step by step \\
\hline \multirow[t]{5}{*}{ 11. Discover self } & 36. Find out your strengths & Explore your own strengths by comparing your skills to those of others \\
\hline & 37. Realize your weakness & $\begin{array}{l}\text { Realize your own weaknesses by comparing and contrasting your skills to } \\
\text { those of others }\end{array}$ \\
\hline & 38. Uncover your prejudices & Find out what types of prejudices you have \\
\hline & 39. Understand your personality & Discover your personality characteristics \\
\hline & $\begin{array}{l}\text { 40. Understand your cultural } \\
\text { background }\end{array}$ & Understand who you are in terms of cultural make up \\
\hline \multirow[t]{3}{*}{ 12. Explore true interests } & 41. Identify excitement & Identify what excites yourself \\
\hline & 42. Identify career interests & Identify career interests \\
\hline & 43. Identify academic areas & Identify intensity of interests towards academic areas \\
\hline \multirow{2}{*}{$\begin{array}{l}\text { 13. Postpone } \\
\text { expectations }\end{array}$} & 44. Balance expectations & Realize big achievements always do not bring about big rewards \\
\hline & 45. Delay little rewards & Put off little rewards to accomplish big goals \\
\hline \multirow[t]{3}{*}{ 14. Model creativity } & 46. Model unusual personality & Dramatize another personality \\
\hline & 47. Focus on unusual ideas & $\begin{array}{l}\text { Consciously insist on generating extraordinary ideas while rejecting } \\
\text { conventional ideas }\end{array}$ \\
\hline & 48. Encourage unusual ideas & Show interests in unusual ideas rather than conventional ideas of others \\
\hline \multirow[t]{2}{*}{ 15. Motivate self } & $\begin{array}{l}\text { 49. Concentrate on personal } \\
\text { value }\end{array}$ & Develop goals according to personal characteristics and values \\
\hline & 50. Concentrate on the beneficial & Determine personal benefits of work in short run and long run \\
\hline
\end{tabular}




\begin{tabular}{|c|c|c|}
\hline $\begin{array}{l}\text { Broad Skills } \\
\text { (2nd Order) }\end{array}$ & $\begin{array}{l}\text { Subskills } \\
\text { (3rd Order) }\end{array}$ & Definition \\
\hline & 51. Find out value of interest & Work in personal interest \\
\hline & 52. Develop goals & Develop achievable goals \\
\hline & 53. Develop successive goals & $\begin{array}{l}\text { Set up successive goals in the order of minor goals to major goals and easy } \\
\text { goals to difficult goals }\end{array}$ \\
\hline \multirow[t]{2}{*}{$\begin{array}{l}\text { 16. Formulate } \\
\text { associations }\end{array}$} & $\begin{array}{l}\text { 54. Formulate knowledge } \\
\text { associations }\end{array}$ & Associate information, ideas or facts with other information, ideas or facts \\
\hline & 55. Construct visual associations & Associate visuals with other visuals \\
\hline \multirow[t]{3}{*}{ 17. Construct analogies } & 56. Make direct analogies & $\begin{array}{l}\text { Explore or construct similarities among seemingly dissimilar ideas, objects or } \\
\text { facts }\end{array}$ \\
\hline & 57. Build personal analogies & Transport yourself into something or someone else to reinterpret the world \\
\hline & 58. Develop symbolic analogies & $\begin{array}{l}\text { Combine contradictory ideas, objects or images or build metaphors to } \\
\text { describe another thing }\end{array}$ \\
\hline
\end{tabular}


Appendix C. EPTS Practical Ability Skills

\begin{tabular}{|c|c|c|}
\hline $\begin{array}{l}\text { Broad Skills } \\
\text { (2nd Order) }\end{array}$ & $\begin{array}{l}\text { Subskills } \\
\text { (3rd Order) }\end{array}$ & Definition \\
\hline \multirow{4}{*}{$\begin{array}{l}\text { Control } \\
\text { impulses }\end{array}$} & 1. Think further before decisions & Make decisions after further thought \\
\hline & 2. Act on a plan & Act on step-by-step plans \\
\hline & 3. Prevent the first act & Postpone the first act to save time for further thinking \\
\hline & 4. Evaluate responses & Evaluate responses before reacting \\
\hline \multirow{3}{*}{$\begin{array}{ll}\text { 2. } & \text { Persevere } \\
\text { without } \\
\text { perseverate }\end{array}$} & 5. Make sensible decisions & Persist on working consciously on achievable goals \\
\hline & 6. Identify achievable goals & Discriminate achievable goals from unachievable goals \\
\hline & 7. Reschedule work & $\begin{array}{l}\text { Delay solutions of problems until the most appropriate time and conditions are } \\
\text { present }\end{array}$ \\
\hline \multirow[t]{4}{*}{ atch orals } & 8. Develop competence profile & Identify individual strengths and weaknesses \\
\hline & 19. Develop interest profile & Identify personal interests \\
\hline & 10. Develop goals profile & Identify personal goals \\
\hline & 11. Evaluate goals & Identify goals that intersect with personal interests and abilities \\
\hline \multirow{3}{*}{$\begin{array}{l}\text { 4. Put into } \\
\text { practice }\end{array}$} & 12. Select ideas & Select ideas based on their doability \\
\hline & 13. Develop plans & Develop implementation plans to apply ideas \\
\hline & 14. Implement plans & Implement ideas according to plans \\
\hline \multirow{3}{*}{$\begin{array}{l}\text { 5. Focus on the } \\
\text { result }\end{array}$} & 15. Develop outlines & Develop outlines of end-products or results \\
\hline & 16. Focus on the result & $\begin{array}{l}\text { Focus on the quality of the end product while ignoring details in the course of } \\
\text { product development }\end{array}$ \\
\hline & 17. Revise the result & $\begin{array}{l}\text { Critically evaluate the quality and standards of the product and revise it according to } \\
\text { characteristics of target audience }\end{array}$ \\
\hline \multirow{2}{*}{$\begin{array}{l}\text { 6. Complete } \\
\text { tasks }\end{array}$} & 18. Find appropriate results & End tasks with satisfactory results \\
\hline & 19. Minimize steps & Reduce the number of steps to finish tasks in time \\
\hline \multirow{3}{*}{$\begin{array}{l}\text { 7. Commit to } \\
\text { goals }\end{array}$} & 20. Generate alternative goals & Generate alternative goals to accomplish \\
\hline & 21. Select goals & Evaluate and select most appropriate goals \\
\hline & 22. Commit to goals & Commit oneself to goals \\
\hline \multirow{3}{*}{$\begin{array}{ll}\text { 8. } & \text { Avoid } \\
\text { procrastinatio } \\
\mathrm{n}\end{array}$} & 23. Set priorities & $\begin{array}{l}\text { Set priorities or order of completion for tasks from minor goals to major goals, easy } \\
\text { goals to difficult goals or most important goals to least important goals }\end{array}$ \\
\hline & 24. Split tasks & $\begin{array}{l}\text { Split tasks into steps, develop completion schedule for steps and complete tasks step } \\
\text { by step }\end{array}$ \\
\hline & 25. Monitor progress & Monitor the progress in each step of the task \\
\hline \multirow{4}{*}{$\begin{array}{ll}\text { 9. } & \text { Assign } \\
& \text { responsibility }\end{array}$} & 26. Take responsibility & Take individual or group responsibility \\
\hline & 27. Asses contribution & Asses personal contribution to success and failure \\
\hline & 28. Accept responsibility & Accept personal contribution to success and failure \\
\hline & 29. Avoid blaming & Avoid blaming others for failures of oneself \\
\hline \multirow{5}{*}{$\begin{array}{l}\text { 10. Manage self- } \\
\text { pity }\end{array}$} & 30. Diagnose reasons of problems & Diagnose personal and external reasons of problems \\
\hline & 31. Revise goals & Develop achievable new goals \\
\hline & 32. Examine past successes & Use past successes to motivate oneself to achieve new goals \\
\hline & 33. Emphasize on progress & Find new areas in which progress is possible and persist on progress in these areas \\
\hline & 34. Manage ego & Uncover and avoid egocentric behaviors \\
\hline \multirow{5}{*}{$\begin{array}{l}\text { 11. Be } \\
\text { Independent }\end{array}$} & 35. Take responsibility & Take individual responsibility in tasks \\
\hline & 36. Make individual decisions & Make individual decisions for personal problems \\
\hline & 37. Increase self-confidence & $\begin{array}{l}\text { Work on tasks for which you have strengths and develop strategies to improve your } \\
\text { weaknesses }\end{array}$ \\
\hline & 38. Develop self-esteem & Evaluate your successes and personal challenges to develop a positive self-image \\
\hline & 39. Become a leader & Take leadership responsibility \\
\hline \multirow{3}{*}{$\begin{array}{l}\text { 12. Overcome } \\
\text { personal } \\
\text { difficulties }\end{array}$} & 40. Develop perseverance & Persist on trying to solve problems \\
\hline & 41. Postpone solutions & Postpone solutions by the best time and conditions \\
\hline & 42. Develop best strategies & Leave strategies that do not work and find new strategies that work \\
\hline \multirow[t]{4}{*}{ 13. Concentrate } & 43. Design environment & Design environments optimal for concentration on tasks \\
\hline & 44. Explore study styles & Discover study styles by trials that support concentration \\
\hline & 45. Order tasks & Design a work schedule for tasks that interrupt concentration \\
\hline & 46. Manage interfering thoughts & Control thoughts that disrupt thinking while on tasks \\
\hline \multirow[t]{4}{*}{ 14. Plan sensibly } & 47. Set priorities & Set priorities in tasks according to certain criteria \\
\hline & 48. Develop timetables & Develop timetables for completing tasks \\
\hline & 49. Partition tasks & Partition tasks into achievable steps \\
\hline & 50. Selectively reject & Say no to new tasks that reduce performance for other tasks \\
\hline
\end{tabular}




\begin{tabular}{|c|c|c|}
\hline $\begin{array}{l}\text { Broad Skills } \\
\text { (2nd Order) }\end{array}$ & $\begin{array}{l}\text { Subskills } \\
\text { (3rd Order) }\end{array}$ & Definition \\
\hline \multirow[t]{3}{*}{ 15. Set priorities } & 51. Identify goals & Identify short-term and long-term goals \\
\hline & 52. Select goals & Select goals that have most priorities \\
\hline & 53. See the big picture & Disregard details and small steps to focus on and accomplish big goals \\
\hline \multirow[t]{5}{*}{$\begin{array}{l}\text { 16. Develop self- } \\
\text { confidence }\end{array}$} & 54. Carry out self-evaluation & $\begin{array}{l}\text { Analyze individual characteristics and identify personal goals and tasks that are } \\
\text { appropriate for individual characteristics }\end{array}$ \\
\hline & 55. Assess past & $\begin{array}{l}\text { Explore past successes, their reasons and results and personal contribution to these } \\
\text { successes }\end{array}$ \\
\hline & 56. Prioritize goals & $\begin{array}{l}\text { Develop strategies to achieve goals step by step by starting with minor goals and } \\
\text { carrying on with big goals }\end{array}$ \\
\hline & 57. Improve basic skills & Identify and improve basic skills that are necessary for tasks to be undertaken \\
\hline & 58. Correct mistakes & Find out mistakes and develop strategies to correct these mistakes \\
\hline \multirow{4}{*}{$\begin{array}{l}\text { 17. Manage } \\
\text { thinking } \\
\text { styles }\end{array}$} & 59. Carry out situational analysis & $\begin{array}{l}\text { Analyze situations or problems to determine what thinking styles might be the most } \\
\text { effective if used }\end{array}$ \\
\hline & 60. Monitor thinking styles & $\begin{array}{l}\text { Systematically observe thinking styles in idea generation and problem solving } \\
\text { processes }\end{array}$ \\
\hline & 61. Do self-critics & $\begin{array}{l}\text { Compare thinking styles being used in idea generation or problem solving to } \\
\text { thinking styles that should be used }\end{array}$ \\
\hline & 62. Change thinking styles & $\begin{array}{l}\text { Change thinking styles that are not effective in problem solving with the most } \\
\text { effective ones }\end{array}$ \\
\hline \multirow{4}{*}{$\begin{array}{l}\text { 18. Use } \\
\text { experience } \\
\text { effectively }\end{array}$} & $\begin{array}{l}\text { 63. Find out negative personal } \\
\text { experience }\end{array}$ & $\begin{array}{l}\text { Uncover ineffective strategies, emotions, behaviors or thoughts in problem solving } \\
\text { in the past }\end{array}$ \\
\hline & $\begin{array}{l}\text { 64. Identify positive personal } \\
\text { experience }\end{array}$ & $\begin{array}{l}\text { Discover effective strategies, emotions, behaviors or thoughts in problem solving in } \\
\text { the past }\end{array}$ \\
\hline & $\begin{array}{l}\text { 65. Analyze negative experience of } \\
\text { others }\end{array}$ & Examine and avoid the use of strategies of others that lead to failures \\
\hline & $\begin{array}{l}\text { 66. Analyze positive experience of } \\
\text { others }\end{array}$ & Explore and use success strategies of others \\
\hline
\end{tabular}




\section{Appendix D. EPTS Lesson Plan Form}

\begin{tabular}{|c|c|}
\hline \multicolumn{2}{|l|}{ LESSC } \\
\hline \multicolumn{2}{|l|}{ A. LESSON INFORMATION } \\
\hline Lesson: Analytical Reading and Creative Writing & Theme/Unit: Habitats \\
\hline Topic: Wetland and Lost Habitats & \begin{tabular}{|l|l|} 
Grade: 6 & Time: 5 hours \\
\end{tabular} \\
\hline \multicolumn{2}{|c|}{$\begin{array}{l}\text { Goal: to analyze, interpret and evaluate a reading text related to habitat, to relate wetlands to habitats, to draw conclusions about habitat } \\
\text { lost, and to write persuasive essays about the need to protect habitats }\end{array}$} \\
\hline \multicolumn{2}{|l|}{ Concepts: habitat, wetland, swamp, endangered species, restoration } \\
\hline \multicolumn{2}{|l|}{ B. LEARNING OUTCOMES } \\
\hline Content Standards & EPTS Learning Outcomes \\
\hline $\begin{array}{l}\text { Students } \\
\text { 1. identify evidence that supports inferences drawn from the text. } \\
\text { 2. determine the main idea, theme or topic of a text. } \\
\text { 3. analyze the development of the main idea throughout the text. } \\
\text { 4. analyze connections or distinctions between ideas or events in a tex } \\
\text { comparisons, analogies, or associations. } \\
\text { 5. examine the structure of a text. } \\
\text { 6. explain how a text presents information sequentially, comparatively etc. }\end{array}$ & $\begin{array}{l}\text { Students } \\
\text { 1. make predictions through cause and effect rela- } \\
\text { tions presented in a text about habitat lost. } \\
\text { 2. evaluate conclusions drawn from the text } \\
\text { through the use of objective evidence and reason- } \\
\text { ing. } \\
\text { 3. write a unique persuasive essay about habitat } \\
\text { lost. } \\
\text { 4. identify an important problem related to the } \\
\text { main idea or theme of the essay. } \\
\text { 5. produce novel solutions for the problem of the } \\
\text { essay. } \\
6 . \text { develop outlines to write a persuasive argument } \\
\text { throughout the essay to support the solution. }\end{array}$ \\
\hline \multicolumn{2}{|l|}{$\begin{array}{l}\text { C. ACTIVITY } \\
\text { Write the instruction in detail for teachers to carry out the lesson appropriately. }\end{array}$} \\
\hline \multicolumn{2}{|c|}{$\begin{array}{l}\text { Activity 1. Reading passage "Wetlands and Lost Habitats:" Read the text, answer questions and discuss answers. } \\
\text { Activity 2. Predictions about habitat lost: Make predictions from evidence about habitat lost presented in a short passage. } \\
\text { Activity 3. Word analysis: Analyze terms related to habitats. } \\
\text { Activity 4. Creative writing: Make a paragraph planning chart to identify claims, reasoning, evidence and connections to write a persuasive } \\
\text { essay about habitat lost; write a persuasive essay using the chart. }\end{array}$} \\
\hline
\end{tabular}

